\title{
The Effect of RME on Mathematics Learning Outcomes Viewed Mathematic Communication Skills
}

\author{
Ningrum Reni Astuti ${ }^{1}$, Gunarhadi ${ }^{2}$, Mintasih $^{3}$
}

\section{ARTICLE INFO}

\section{Article History:}

Received 20.03.2019

Received in revised form

26.11.2019

Accepted

Available online 01.01.2020

\begin{abstract}
This study aims to determine whether or not arethere 1) differences in mathematics learning outcomes between students who take learning with the Realistic Mathematic Education (RME) approach and students who take learning with Scientific models; 2) differences in mathematics learning outcomes between students who have high, medium, and low mathematical communication skills; 3) the interaction between the learning models used with mathematical communication skills in improving mathematics learning outcomes. This research is an experimental research with a $2 \times 3$ factorial design, with a population of all grade 3 students at the Kalam Kudus Christian Elementary School in 2017/2018 Academic Year. Samples from this study were 50 students taken with the Simple Random Sampling technique, each taken 25 people for the experimental group and 25 people for the control group. Results of this study 1) Mathematics learning outcomes of students who take lessons with the RME approach are better than those who follow learning with Scientific approaches. 2) There are differences in mathematics learning outcomes between students who have high, medium, and low mathematical communication skills. 3) There is no interaction between learning models with mathematical communication skills in improving mathematics learning outcomes.
\end{abstract}

CC IJERE. All rights reserved

Keywords:

Mathematics; realistic mathematic education; scientific; mathematical communication skills.

\section{INTRODUCTION}

Based on government regulations for Mathematics in elementary schools states that:

Mathematics subjects need to be given to all students starting from elementary school to equip students with the ability to think logically, analytically, systematically, critically, and creatively, as well as the ability to cooperate. These competencies are needed so that students can have the ability to obtain, manage, and use information to survive in a situation that is always changing, uncertain, and competitive (Ministry of National Education, 2006: 416)

Based on this definition gives an understanding that Mathematics is a branch of knowledge that is built with the ability to think logically, analytically, systematically, critically, and creatively, as well as the ability to cooperate. Mathematics is needed in daily life for students to have the ability to obtain, manage, and utilize information to survive in a situation that is always changing, uncertain, and competitive. Mathematics subjects need to be done wisely so as not to negatively impact the lives of students. In every opportunity, learning mathematics should begin with the introduction of problems that are appropriate to the situation (contextual problem). By proposing contextual problems, students are gradually guided to master mathematical concepts. To improve the effectiveness of learning, schools are expected to use information and communication technology such as computers, teaching aids, or other media.But the thing that happens when students hear math is the dismissal of the notion that mathematics is "scourge", difficult lessons. No wonder that in general the results of students' mathematics learning of mathematical concepts are still at a low level. The assumptions even appear "for what is learning algebraic mathematics, trigometry, which does not know what is the point in our lives later". Learning mathematics in Indonesia can be said to be far from the expected goals.

\section{Situation of the Problem}

Indonesia has participated in the Programmed or International Student Assessment (PISA) which was first held in 2000. PISA is an international scale assessment program that aims to find out to what extent students (aged 15 years) can apply the knowledge they have learned in school. One focus of PISA is in the field of mathematics in addition to discussion and science. However, even though Indonesia has been involved since the initial implementation of PISA, the results achieved by Indonesian students in 2012 are far 
from satisfying. From the results of PISA Mathematics in 2012, it was found that almost half of Indonesian students (ie 43.5\%) were unable to solve the simplest PISA questions (the most basic PISA tasks). About one third of Indonesian students (ie 33.1\%) can only work on problems if the questions from contextual questions are explicitly provided and all data needed to work on the questions is given precisely. Only $0.1 \%$ of Indonesian students are able to develop and work on mathematical modeling that requires thinking and reasoning skills. To measure students' ability to apply the knowledge they have learned, PISA uses questions related to real life. Therefore learning mathematics education should be about real or real things because it is a branch of science that is very close to students. The use of approaches, models, or learning media must reach the understanding of children so that they feel that mathematics is a real problem in everyday life that they normally encounter.

In reality on the ground it can be proven by the acquisition of grade 3 mathematics in elementary schools is still not satisfactory because it has not reached the predetermined completeness standard. This fact is based on the results of observations made on grade 3 students at Kalam Kudus Christian Elementary School Surakarta. The average grade of Mathematics grade 3 at the end of semester 2 obtained the following data.

Table 1.

Table 1. Mathematics Learning Outcomes Grade 3 Students at SD Kalam Kudus Surakarta

\begin{tabular}{ccccc}
\hline Year & $\begin{array}{c}\text { Rata-rata Nilai } \\
\text { Matematika }\end{array}$ & $\begin{array}{c}\text { Standard } \\
(\text { KKM })\end{array}$ & $\begin{array}{c}\text { Achievements } \geq \\
\text { KKM }(\%)\end{array}$ & $\begin{array}{c}\text { Achievements } \\
\text { KKM }(\%)\end{array}$ \\
\hline $2013 / 2014$ & 73,30 & 70 & 72,05 & 27,95 \\
$2014 / 2015$ & 73,08 & 70 & 71,87 & 29,13 \\
$2015 / 2016$ & 70,65 & 70 & 65,55 & 35,45 \\
\hline
\end{tabular}

Source: Curriculum Section

Based on the table it can be seen that the overall completeness each year does not exceed $73 \%$ of the total number of students. This raises questions about the quality of Mathematics learning carried out so far. Teaching is still centered on the teacher, so the acceptance of students is less satisfying. The selection of the right learning approach is also very necessary in the learning process.

The teaching and learning process is an important communication access, it can be stated as follows:

Teaching and learning processes are those that contain teacher-student interaction activities and reciprocal communication that takes place in educational situations to achieve learning goals. Interaction and mutual communication between teacher and student are the main characteristics and conditions for the ongoing teaching and learning process. Rustaman (2005: 5).

From this description it can be concluded that the expected mathematics education is education that implements a learning model that involves students in the learning process. Students can be directly involved in the learning process so that they are expected to be able to understand concepts, increase their knowledge and live the mathematics in their daily lives.The learning approach must be in accordance with the material to be taught and can optimize the learning atmosphere. One approach that brings students' minds into learning and actively involves students is the Realistic Mathematic Education (RME) approach.

The Realistic Mathematic Education (RME) Approach is an approach in learning mathematics in the Netherlands. The word "realistic" is often misinterpreted as "real-world", which is the real world. Realistic Mathematics Education is not an approach to learning mathematics which must always use everyday problems. The use of the word "realistic" actually comes from the Dutch "zich realizer" which means "to imagine" or "to image" (Van den Heuvel-Panhuizen, 1998). The use of the word "realistic" does not just 
indicate a connection with the real world (real-world) but rather refers to the focus of Realistic Mathematics Education in placing emphasis on the use of a situation that can be imagined (imagineable) by students.

Besides RME, the learning approach that actively involves students is in the latest Indonesian curriculum, the 2013 curriculum which carries the learning approach that is no less innovative, namely the Scientific approach. The scientific approach is learning that adopts scientific steps in building knowledge through scientific methods or more commonly said approaches in the 2013 curriculum. In learning the scientific approach applies the 5M system of observing, asking, trying, processing information, and communicating it. So the learning process with a scientific approach is effective for student learning outcomes and communication.

The similarity between the two approaches is that, together with a student-centered approach, the teacher is only a facilitator, both emphasizing the learning process not just the results of student achievement. While the difference between the two approaches is that RME is specifically designed for mathematical subjects that are actually very close to the world of children so that with this approach students can feel that mathematics is the problems of life that they find every day, emphasizing the real things that they found. Whereas Scientific does not focus on just one subject, emphasizing a scientific approach, where students dig up information and try to solve their own problems, the media used is diverse, it can be from books, pictures, real things, and so forth.

Communication is the most important thing in the learning process with the learning approach. There are two important reasons put forward by Baroody (in Lim and Chew, 2007), why communication is one of the focuses in learning mathematics. First, mathematics is basically a language for mathematics itself. Mathematics is not only a thinking tool that helps us to find patterns, solve problems and draw conclusions, but is also a tool to communicate our thoughts about ideas clearly, precisely and concisely. In fact, mathematics is considered a "universal language" with unique symbols and structures. Everyone in the world can use it to communicate mathematical information even though their native language is different.

One of the basic competencies of elementary schools that is appropriate to support the existence of evidence-proof material directly and requires skills in using general reasoning in learning is KD 1.4 Perform mixed count operations. The concept fosters the ability to think, work and be scientific and communicate it as an important aspect of life skills.

In Robert K. Sembiring's research (2008) entitled "Reforming mathematics learning in Indonesian classrooms through RME" with the context of his research is the current reform movement which adopts realistic mathematics education (RME) theory, known as Indonesian Realistic Mathematics Education (PMRI), Research conducted in two teaching cycles of experiments in two elementary schools found that the availability of RME was an important component in the success of mathematics, especially in supporting students and teachers based on mathematics learning activities. Most students and teachers in the two elementary schools are actively involved in developing the material, they feel mathematics is found in everyday life and recognize that their students experience mathematics through learning in class and avoid standard difficulties.

Based on this research, this study provides a renewal and proof of how the effect of RME compared to other approaches, in this study using a comparative approach to the Scientific approach which is considered equally effective for improving student learning outcomes. In addition, this study wants to examine the relationship with students' mathematical communication that cannot be separated from mathematics itself.

\section{Aim of the Study}

This study aims to determine whether or not arethere 1) differences in mathematics learning outcomes between students who take learning with the Realistic Mathematic Education (RME) approach and students who take learning with Scientific models; 2) differences in mathematics learning outcomes between students who have high, medium, and low mathematical communication skills; 3) the interaction between the learning models used with mathematical communication skills in improving mathematics learning outcomes. 


\section{METHOD}

The study was an experimental study conducted in grade 3 of the Kalam Kudus Christian Elementary School in Surakarta. The population in this study were all grade 3 students of the Kalam Kudus Christian Elementary School in 2017/2018 Academic Year. Samples from this study were 50 students taken with the Simple Random Sampling technique, each taken 25 people for the experimental group and 25 people for the control group. Each class contains 12 girls and 13 boys that average age of 8 years old of various ethnicities. Data retrieval of mathematics learning outcomes is done by using test techniques, while mathematical communication skills data using questionnaire techniques. Analysis of the data used is a two-way analysis of variance followed by the Scheffe test. The research design used was a $2 \times 3$ factorial design with two-way variance analysis (ANAVA) techniques.

Table 2. Factorial Design

\begin{tabular}{cccc}
\hline \multirow{2}{*}{ LEARNING APPROACHES(A) } & MATHEMATICAL COMMUNICATION SKÍLLS (B) \\
& HIGH (B1) & MEDIUM (B2) & LOW (B3) \\
\hline RME (A1) & A1B1 & A1B2 & A1B3 \\
SCIENTIFIC (A2) & A2B1 & A2B2 & A2B3 \\
\hline
\end{tabular}

Note:

A1 : Mathematic Realistic Education Learning Approach

A2 : Scientific Learning Approach

B1 : High mathematical communication skills

B2 : Medium mathematical communication skills

B3 : Low mathematical communication skills

A1B1 : Group of students who have high mathematical communication skills who are treated with a Realistic Mathematic Education (RME) learning approach.

A1B2 : Group of students who have moderate mathematical communication skills who are treated with a Realistic Mathematic Education (RME) learning approach.

A1B3 : Group of students who have low mathematical communication skills who are treated with a Realistic Mathematic Education (RME) learning approach.

A2B1 : Group of students who have high mathematical communication skills who are treated Scientific learning approaches.

A2B2 : Groups of students who have moderate mathematical communication skills who are treated Scientific learning approaches.

A2B3 : Groups of students who have low mathematical communication skills who are treated Scientific learning approaches.

\section{Material}

a. Balance Test

A balance test is a prerequisite for an experiment. The value used is the value of Final Examination Even Semester Mathematics class 3 year of 2016/2017. Before a balance test is performed, the normality test and the homogeneity of the initial ability test are first performed.

Table 3.Summary of Normality Test 


\begin{tabular}{|c|c|c|c|c|c|c|}
\hline & \multirow{2}{*}{$\begin{array}{l}\text { Learning } \\
\text { Approach }\end{array}$} & \multicolumn{3}{|c|}{ Shapiro-Wilk } & \multirow[t]{2}{*}{ Decision } & \multirow[t]{2}{*}{ Conclusion } \\
\hline & & Statistic & Df & Sig. & & \\
\hline \multirow[t]{2}{*}{ Pretest } & $R M E$ & 0.942 & 25 & 0.169 & Ho accepted & $\begin{array}{c}\text { Normal } \\
\text { distribution }\end{array}$ \\
\hline & Scientific & 0.939 & 25 & 0.137 & Ho accepted & $\begin{array}{c}\text { Normal } \\
\text { distribution }\end{array}$ \\
\hline
\end{tabular}

Results of normality test of pretest from the RME and Scientific groups indicate of Sig. $>0.05$ thus data of initial mathematical ability from two groups came from populations that were normally distributed.

Tabel 4.Summary of Homogeneity Test

\begin{tabular}{cccccl}
\hline F & Df1 & df2 & Sig. & Decision & Conclusion \\
\hline 0,000 & 1 & 48 & 0,995 & Ho accepted & Homogeneous \\
\hline
\end{tabular}

Results of homogeneity test showed the initial ability Sig. $>0.05$ means that both sample groups come from homogeneous populations.

Table5.Results of of Independent-Sample T-Test

\begin{tabular}{|c|c|c|c|c|c|c|}
\hline & & \multicolumn{2}{|c|}{$\begin{array}{l}\text { Levene's Test for } \\
\text { Equality of Variances }\end{array}$} & \multicolumn{3}{|c|}{ t-test for Equality of Means } \\
\hline & & $\mathrm{F}$ & Sig. & $\mathrm{T}$ & $\mathrm{df}$ & $\begin{array}{l}\text { Sig. (2- } \\
\text { tailed) }\end{array}$ \\
\hline \multirow[t]{2}{*}{ Pretest } & $\begin{array}{l}\text { Equal variances } \\
\text { assumed }\end{array}$ & 0.000 & 0.995 & 1.473 & 48 & 0.147 \\
\hline & $\begin{array}{l}\text { Equal variances } \\
\text { not assumed }\end{array}$ & & & 1.473 & 48 & 0.147 \\
\hline
\end{tabular}

Based on the table above shows the value of t-statistic value of 1.473 with Sig. (2-tailed) $>0.05$ so $\mathrm{H}_{0}$ which states "there is no difference between the average mathematical pretest scores of the experimental group and the control group" is accepted. So it can be concluded that the initial ability of students before being treated equally between the two groups.

\section{b. Assumptionsof ANOVA}

Data analysis requirements using parametric statistics are data obtained in normal and homogeneous distribution, then before anava test is carried out normality and homogeneity tests. The normality test is done by the ShapiroWilk test with the results as the following table.

Table 6. Summary of Normality Test

\begin{tabular}{lccccc}
\hline & Group & \multicolumn{3}{c}{ Shapiro-Wilk } & Conclusion \\
& Statistic & Df & Sig. & \\
\hline RME approach & 0.947 & 25 & 0.213 & Normal distribution \\
Scientific Approach & 0.926 & 25 & 0.070 & Normal distribution \\
\hline
\end{tabular}




\begin{tabular}{|c|c|c|c|c|}
\hline High mathematical communication skills & 0.907 & 13 & 0.168 & Normal distribution \\
\hline Medium mathematical communication skills & 0.945 & 31 & 0.111 & Normal distribution \\
\hline Low mathematical communication skills & 0.975 & 6 & 0.923 & Normal distribution \\
\hline RME; High mathematical communication skills & 0.870 & 10 & 0.100 & Normal distribution \\
\hline $\begin{array}{l}\text { RME; Medium mathematical communication } \\
\text { skills }\end{array}$ & 0.875 & 12 & 0.076 & Normal distribution \\
\hline RME; Low mathematical communication skills & 0.942 & 3 & 0.537 & Normal distribution \\
\hline $\begin{array}{l}\text { Scientific; High mathematical communication } \\
\text { skills }\end{array}$ & 0.964 & 3 & 0.637 & Normal distribution \\
\hline $\begin{array}{l}\text { Scientific; } \quad \text { Medium } \\
\text { communication skills }\end{array}$ & 0.918 & 19 & 0.102 & Normal distribution \\
\hline $\begin{array}{l}\text { Scientific; Low mathematical communication } \\
\text { skills }\end{array}$ & 1.000 & 3 & 1.000 & Normal distribution \\
\hline
\end{tabular}

Results of normality test of mathematics learning outcomes in each group showed a significance level of Shapiro-Wilk $>0.05$ so $\mathrm{H}_{0}$ which states that the data came from populations that were normally distributed was accepted. Thus it can be concluded that the mathematics learning outcomes data in each group comes from populations that are normally distributed.

Homogeneity test using Levene's Test is shown as the following table.

Tabel 7.Homogeneity of Variance Results

\begin{tabular}{rccccc}
\hline F & df1 & df2 & Sig. & Decision & Conclusion \\
\hline 0.257 & 5 & 44 & 0.934 & Ho accepted & Homogeneous \\
\hline
\end{tabular}

Based results of the analysis of data obtained Levene F-statistics of 0.257 with a significance level of 0.934 which is greater than the cut-off value of 0.05 so $\mathrm{H}_{0}$ which states that homogeneous population variance is accepted. Thus it can be concluded that the homogeneous data requirements for hypothesis testing with Two Ways Anova have been fulfilled.

\section{c. Hypothesis testing}

Hypothesis testing is done by Two Way Anava test. After statistical analysis with SPSS Version 16, the results of hypothesis testing such as the following table are obtained.

Tabel 8.Summary of Hypothesis Testing Results

\begin{tabular}{lrrrrr}
\hline \multicolumn{1}{c}{ Source } & $\begin{array}{c}\text { Type III Sum } \\
\text { of Squares }\end{array}$ & Df & Mean Square & F & \multicolumn{1}{c}{ Sig. } \\
\hline LO & 1206.819 & 1 & 1206.819 & 12.225 & 0.001 \\
MCS & 4461.668 & 2 & 2230.834 & 22.598 & 0.000 \\
LO*MCS & 507.788 & 2 & 253.894 & 2.572 & 0.088 \\
Error & 4343.565 & 44 & 98.717 & &
\end{tabular}


Total $254780.000 \quad 50$

1) Difference Test Results of Mathematics Learning Outcomes of Students in Learning with RME Approach and Scientific Approach (A1: A2)

From the calculation of Anova (Table 8) obtained F-statistics 12.225 with Sig $0.001<0.05$ means Ho is rejected and $\mathrm{H} 1$ accepted. Means there is a significant difference in mathematics learning outcomes between students who following the learning of RME approach with Scientific Approach. Students who following the RME Scientific Approach achieve higher learning outcomes than students who following Scientific Approach. The first hypothesis consists of only two factors, namely the RME approach and the Scientific approach so that there is no need to do a double comparison test but only look at the marginal mean values shown in the following table

Table 9. Comparison of Mathematical Learning Outcomes Based on Learning approaches

\begin{tabular}{ccccc}
\hline \multirow{2}{*}{$\begin{array}{c}\text { Learning } \\
\text { approaches }\end{array}$} & Mean & Std. Error & \multicolumn{2}{c}{$95 \%$ Confidence Interval } \\
\cline { 3 - 4 } & & & Lower Bound & Upper Bound \\
\hline RME & 73.622 & 2.381 & 68.825 & 78.420 \\
Scientific & 60.749 & 2.809 & 55.088 & 66.409 \\
\hline
\end{tabular}

Average learning outcomes of mathematics in students who take learning with the RME approach is 73.622 while the average value of students who take learning with the Scientific approach is 60.749. Thus it can be concluded that the RME approach is better than the Scientific model approach to mathematics learning outcomes. The existence of these differences, according to Ningsih (2014) due to the Realistic Mathematic Education (RME) approach in learning mathematics has several advantages compared to the Scientific approach, namely (1) RME provides students with a clear and operational understanding of the relationship between mathematics and everyday life and about the usefulness of mathematics in general to humans. (2) RME gives students a clear and operational understanding that the way to solve a problem or problem does not have to be singular, and does not have to be the same between one person and another person. (3) RME combines the strengths of various other learning approaches that are also considered "superior". (4) RME is complete (detailed), detailed and operational.

Results of this study support research conducted by Pratama entitled "Differences in Realistic Mathematic Education (RME) Approach and Open Ended Against Student Learning Outcomes in Flat Build Class VII MTs Al Huda Bandung Tulungagung Academic Year 2016/2017" which states there are significant differences between learning with the Realistic Mathematic Education (RME) approach with the Open Ended approach to mathematics learning outcomes. Mathematics learning outcomes of students who take learning with the RME approach are higher than students who take learning with the Open Ended approach.The results of this study support research conducted by Tarigan and Sinaga (2015) entitled "Differences in Student Learning Outcomes in a Realistic Approach and Expository Approach in Mathematics Subjects in Class IV SDN 101880 Tanjung Morawa" which states there are significant differences between learning with a Realistic approach to the approach Expository of mathematics learning outcomes. Mathematics learning outcomes of students who take learning with the Realistic approach are higher than students who take learning with the Expository approach.

2) Results of Differences Test in Mathematics Learning Outcomes between Students Who Have High, Medium, and Low Mathematical Communication Skills (B1: B2: B3)

From the calculation of Anova (Table 8) obtained F-statistics 22.598 with Sig $0.000<0.05$ means Ho is rejected and $\mathrm{H} 2$ accepted, so Ho stated that "there is no difference in mathematics learning outcomes 
between students who have high mathematical communication skills, have medium mathematical communication skills, and have low mathematical communication skills" are rejected. This means that there are differences in mathematics learning outcomes between students who have high mathematical communication skills, have medium mathematical communication skills, and have low mathematical communication skills. From the results of the analysis it can be concluded that there are differences or effects of mathematical communication skills on mathematics learning outcomes. Based on the analysis of multiple comparisons with Scheffe, a comparison of mathematics learning outcomes of students who have high, medium, and low mathematical communication skills is presented as the following table.

Table 10 Comparison of Mathematical Learning Outcomes Based on Mathematical Communication Skills

\begin{tabular}{ccccc}
\hline Mathematical & $\mathrm{N}$ & \multicolumn{3}{c}{ Subset } \\
\cline { 3 - 4 } communication skills & 6 & 1 & 2 & 3 \\
\hline High & 31 & 49.00 & 67.48 & \\
Medium & 13 & & & 84.62 \\
Low & & 1.000 & 1.000 & 1.000 \\
\hline
\end{tabular}

Based on the data in the above table it can be concluded that among students who have high, medium, and low mathematical communication skills have different mathematical learning outcomes. From the Scheffe test results the value of mathematics learning outcomes of students who have low mathematical communication skills are in subset 1 with an average value of 49.00, moderate mathematical communication skills in subset 2 with an average value of 67.48 and high mathematical communication skills at subset 3 with an average value of 84.62 . Thus it can be concluded that students who have high learning mathematical communication skills have better mathematical learning outcomes than students who have moderate mathematical communication skills. Likewise, students who have mathematical communication skills are having better mathematics learning outcomes than students who have low mathematical communication skills. The Mathematical Communication Theory put forward by Baroody (2016: 17) supports the results of this study that mathematical communication is the process of communicating and associating ideas with mathematics so that it is more practical, systematic, and efficient. Besides communicating ideas with the language of mathematics can change the learning situation, from passive students to active, from a single process and results to a variety of ways and solutions. Thus, students with high mathematical communication skills will achieve higher learning outcomes compared to students with low mathematical communication skills.

This finding supports the results of research conducted by Rizky (2016) which states that there are differences in mathematical communication skills possessed by students in class VII of Maarif Jepara Middle School. Indicators of students' mathematical communication skills can be seen from (1) The ability to express mathematical ideas through oral, written, and demonstrate and visualize them. (2) The ability to understand, interpret, and evaluate mathematical ideas both verbally, in writing, and in other visual forms. (3) The ability to use terms, mathematical notations and structures to present ideas, describe relationships with situation models.

The findings of this study support the results of previous research conducted by Umar (2012) with the title "Building Mathematical Communication Capabilities in Mathematics Learning" which suggests that mathematical communication skills in mathematical learning really need to be developed. This is because through mathematical communication students can organize mathematical thinking both verbally and in writing. In addition, students can also provide appropriate responses between students and the media in the learning process. Even in social relationships, someone who has good communication skills will tend to be easier to adapt to anyone where he is in a community, which in 
turn will be a successful person in his life. Relevance with this research are both using a mathematical communication approach.

3) Results of Interaction Effect between Learning Approaches and Mathematical Communication Skills on Learning Outcomes of Mathematics

From the calculation of Anova (Table 8) obtained F-statistics 2,572 with Sig $0.088>0.05$ means Ho accepted and $\mathrm{H} 3$ rejected, it can be concluded that $\mathrm{H}_{0}$ which states "there is no interaction effect between learning approach (RME and Scientific) with mathematical communication skills (high, medium, and low) on mathematics learning outcomes" accepted. Because there is no interaction between learning approaches and mathematical communication skills, the comparison between RME and Scientific learning approaches for each category of mathematical communication skills follows their marginal comparison. From the fact that there is no such interaction, so the characteristic differences between the RME and Scientific approaches for each category of mathematical communication skills are the same. The mean marginal value can be seen in the following table.

Table 11Comparison of Mathematics Learning Outcomes Based on Learning Approaches and Mathematical Communication Skills

\begin{tabular}{clcccc}
\hline \multirow{2}{*}{$\begin{array}{c}\text { Learning } \\
\text { Approache }\end{array}$} & $\begin{array}{c}\text { Mathematical } \\
\text { Communication }\end{array}$ & Mean & & \multicolumn{2}{c}{$95 \%$ Confidence Interval } \\
\cline { 5 - 6 } Skills & & Std. Error & & \\
\cline { 5 - 6 } & & & & Lower Bound & Upper Bound \\
\hline \multirow{2}{*}{ Scientific } & High & 62,000 & 5,736 & 50,439 & 73,561 \\
& Medium & 73,667 & 2,868 & 67,886 & 79,447 \\
& Low & 85,200 & 3,142 & 78,868 & 91,532 \\
\hline & Hedigh & 36,000 & 5,736 & 24,439 & 47,561 \\
& Low & 63,579 & 2,279 & 58,985 & 68,173 \\
\hline
\end{tabular}

Judging from the marginal average, the average value of students who take learning with the RME approach is always higher than the average value of students who take learning with Scientific approaches, both at the level of mathematical communication skills high, medium, or low. Because there is no interaction, this also applies to students with high mathematical communication skills, who get better mathematics learning outcomes than students with moderate mathematical communication skills. Likewise, students with mathematical communication skills are getting better grades than students with low mathematical communication skills.

According to Ghozali (2005) moderator variables are variables that strengthen or weaken the relationship between two variables. In this study, mathematical communication skills that act as moderator variables cannot strengthen the relationship between learning approaches and mathematics learning outcomes. Interaction of RME approach * High KKM learning outcomes are always better than Medium KKM and Low KKM. Likewise, the interaction of Scientific * High KKM approaches is always better than Medium and Low KKM. That is, in each learning approach, students who have high, medium, or low mathematical communication skills, are equally good at improving mathematics learning outcomes.

Factors causing no interaction, can be caused by other moderator factors both student factors (interests, motivation, learning styles, etc.) and factors outside students (learning media, teaching materials, etc.). According to Mulyanto (2016) the possible factors causing the absence of this interaction are the presence of other factors that interact with the learning approach to student learning outcomes, for example learning styles. For example the results of the research Solihatin (2011: 1), Liyusri \& Situmorang (2013: 64), and Marpaung \& Napitupulu (2014: 25) show the interaction of influence between the learning approach with learning styles on student learning outcomes. 
The findings of this study support the results of previous studies conducted by Erwin, Tellu and Kundera (2015) that there is no interaction between learning approaches and students' critical thinking skills towards learning outcomes in Biology lessons at SMA Negeri 4 Palu. The findings of this study support the results of previous studies conducted by Widyatiningtyas et al. (2015) that there was no significant interaction between the learning approach and the initial mathematical ability of mathematical mathematical communication skills in high school students in Bandung. The findings of this study support the results of previous studies conducted by Tijayanti and Marzuki (2014) that there is no significant interaction between learning methods and types of intelligence on the development of mathematical communication skills of students in SMA Negeri 1 Suela, East Lombok. Several other studies in different subjects also show the results of the lack of interaction of influence between learning approaches with mathematical communication skills on student learning outcomes. The results of Erwin, Tellu and Kundera (2015) research found that there was no interaction of influence between the learning approach and mathematical communication skills on Biology learning outcomes of students in SMA Negeri 4 Palu.

\section{RESULT, DISCUSSION, AND SUGGESTIONS}

Based on the results of research and discussion, can be concluded as follows (1) Mathematics learning outcomes of students who take learning with the Realistic Mathematic Education (RME) approach are better than mathematics learning outcomes of students who take learning with the Scientific approach. This means that the learning approach has a significant effect on student mathematics learning outcomes. (2) Mathematics learning outcomes of students who have high mathematical communication skills are better than mathematics learning outcomes of students who have medium mathematical communication skills, and mathematics learning outcomes of students who have medium mathematical communication skills are better than mathematics learning outcomes of students who have low mathematical communication skills. This means that students mathematical communication skills have a significant influence on mathematics learning outcomes. (3) There is no interaction effect between learning approachs and mathematical communication skills of students mathematics learning outcomes. (a) In learning with the RME approach and the Scientific approach, students with high mathematical communication skills are better at learning outcomes than students with medium mathematical communication skills, and students with medium mathematical communication skills are better at learning outcomes than students with low mathematical communication skills. (b) Mathematics learning outcomes of students who take lessons with the RME approach are always better than students who take learning with Scientific approaches, both at high, medium, and low levels of mathematical communication skills.

Based on the conclusions from this study, teacher is suggested to improve regular meetings in the Teachers Working Group to discuss on the use of RME learning. Principal suggested suppoeting teachers in implementing learning innovation through workshop or in house training.

Further research is suggested to expand the research sample at puclic and private elementary school in Central Java area, so that research result can more be generalized. Futhermore, there is still a need for research to analyze the difference of mathematics learning outcomes by comparing between RME learning with other model, so the result will be more developed.

\section{REFERENCES}

Cai Jinfa \& Patricia. (2000). Fostering mathematical thinking through multiple solutions. MathematicsTeachingin theMiddle School (MTMS). Volume 5 No 8 April .www.nctm.org/ $\mathrm{mtms} / 2000 / 04 /$ index.htm,

Clark, Karen K, dkk. (2005). Strategies for building mathematical communication in the middle school classroom: modeled in professional development, implemented in the classroom. Cur re $n$ t Is s u es $i$ nMiddle LevelEducation,11(2),1-12.

Darsono. (2017). The need textbook writing of children's story based on character education. International Journal of Educational Research Review, 3(2), 1-8. 
David K. Pugalle, Barbara Bissell, Corey Lock, Patricia Douville (2003). The mathematics educatioaninto the 21 century Project Proceedings of the InternationalConference The Decidableand the Undecidablein Mathematics Education Brno,CzechRepublic,September .Hal: 238-241.

Hartanto (2012). Mengembangkan Kreativitas Siswa Melalui Pembelajaran Matematika Dengan Pendekatan Inkuiri. Jurnal Kependidikan Triadik 14(1):11-18.

Martin, P. W. (1996). Code-switching in the primary classroom: One response to the planned and unplanned language environment in Brunei. Journal of Multilingual and Multicultural Development, 17(1-4), 128 144.

Mulyanto, H., Gunarhadi, Indriayu, M. (2018). The effect of problem based learning model on student mathematics learning outcomes viewed from critical thinking skills. International Journal of Educational Research Review, 3(2),37-45.

Ningsih, Seri. (2014). Realistic mathematics education: Model alternatif pembelajaran matematika Sekolah. Jurnal Pendidikan Matematika (JPM), 1(2), 73-94.

Nisa, T. F. (2011). Pembelajaran Matematika dengan Setting Model Treffinger Untuk Mengembangkan Kreativitas Siswa. Pedagogia 1(1): 35-50.

Noraini, I. (1999, May). Linguistic aspects of mathematics education: How precise do teachers need to be. In Y.P. Leong, M.A. Clements (Eds) (1999). Proceedings of theFourth Annual Conference of the Department of Science and Mathematics Education. Gadong: ETC Universiti Brunei Darussalam

Novikasari, I. (2007). Realistic Mathematics Education (RME):Pendekatan Pendidikan Matematika dalam Konsep dan Realitas. Insania 2(1): 93-106.

Nurlaelah (2012). Penerapan Model Cooperative Learning Tipe Student Teams Achievement Division (STAD) dalam Meningkatkan Aktivitas Dan Hasil.

Purwoko (2013). Meningkatkan Kreativitas dan Prestasi Matematika dengan pendekatan realistics mathematics education (RME) pada Siswa Sekolah Menengah Atas. Penabur 4(5): 1-18.

Pourdavood,P.G. \& Wachira,P. (2015). Importance of mathematical communication and discourse in secondary classrooms. Global Journal of Science Frontier Research: F Mathematics and Decision Sciences, 15 (10), 9-20.

Salleh, R. (2005). Undesirable academic performance in science: Is it because of language? In H.S Dhinsa, I.J. Kyeleve. O. Chukwo \& J.S.H.Q Perera (Eds) (2005). Proceedings ofthe 10thannual international conference of the Sultan Hassanal Bolkiah Institute ofEducation (pp. 117 - 125). Gadong: ETC - Universiti Brunei Darussalam.

Şimşek, Y. (2017). The evaluation of the application of transported education by teachers. International Journal of Educational Research Review, 2(1), 41-48. DOI: 10.24331/ijere.309972.

Supardi. (2008). Peran Berpikir Kreatif dalam Proses Pembelajaran Matematika. Jurnal Formatif 2(3): $248-262$.

Tarigan, D. Dan Sinaga, E.M. (2015). Perbedaan Hasil Belajar Siswa dalam Pendekatan Realistik dengan Pendekatan Ekspositori pada Mata Pelajaran Matematika Kelas IV SDN 101880 Tanjung Morawa. KREANO: Jurnal Matematika Kreatif dan Inovatif. Vol.6(1):7-11.

Umar, W. (2012). Membangun Kemampuan Komunikasi Matematis DalamPembelajaran Matematika. Infinity. Jurnal Ilmiah Program Studi Matematika STKIP Siliwangi Bandung, 1(1).

Wijaya, Ariyadi. (2012). "Pendidikan Matematika Realistik". Graha Ilmu. Yogyakarta.

Zubainur, C. M. (2014). How a realistic mathematics educational approach affect students' activities in primary schools? Procedia - Social and Behavioral Sciences, 159, $309-313$ 